\title{
Changes in anterior chamber eye during accommodation as assessed using a Dual Scheimpflug system
}

\author{
Mudanças na câmara anterior do olho durante a acomodação avaliadas por meio de sistema de \\ Scheimpflug duplo
}

Alberto Domínguez-Vicent ${ }^{1}$, Daniel Monsálvez-Romín ${ }^{1}$, César Albarrán-Diego ${ }^{1}$, Vicent Sanchis-Jurado ${ }^{1}$, Robert Montés-Micó ${ }^{1}$

\begin{abstract}
Purpose: To study the changes in anterior chamber depth (ACD), anterior chamber angle (ACA), and pupil diameter (PD) during accommodation.

Methods: Eighty eyes of 80 subjects, aged 22 to 40 years, were included. The rotating Dual Scheimpflug and a Placido disc system (Galilei G4, Ziemer Ophthalmic Systems AG, Switzerland) was used to measure the changes in ACD, ACA, and PD during accommodation. ACD measurement was taken for the central zone and for 4 more positions, each in different orientation (nasal, superior, temporal and inferior), $4 \mathrm{~mm}$ away from the centre. ACA was measured for the whole eye as well for the nasal, superior, temporal, and inferior quadrants. These metrics were obtained for various accommodation stimuli, ranging from +1 D to -4D in 1-D steps, Results: For a given position, the ACD did not vary significantly with accommodation. For the central $A C D$, the percentage of relative change between far and near vision was $-4.11 \%$. The ACA was significantly lower at the inferior, temporal and superior positions. There was no change in the ACA of the whole eye and that of the nasal orientation. These two eye metrics were significantly lower in the superior-nasal than in the inferior-temporal region. At each vergence studied, the PD decreased significantly with accommodation. The relative change after the $-4 \mathrm{D}$ stimulus was $-8.13 \%$.

Conclusion: ACA and PD varied significantly with accommodation, whereas no such variation of ACD was observed. Further, the anterior chamber was found to be asymmetrical, with the nasal-superior area becoming significantly shallower than the inferior temporal region.
\end{abstract}

Keywords: Anterior chamber; Pupil; Accommodation, ocular; Techniques, measures, measurement equipment

\section{RESUMO}

Objetivo: Estudar as mudanças na profundidade da câmara anterior (ACD), ângulo da câmara anterior (ACA) e diâmetro da pupila (PD) durante a acomodação.

Métodos: Foram incluídos 80 ol hos de 80 indivíduos com idades entre 22 e 40 anos. Um sistema rotacional de Scheimpflug duplo acoplado a um sistema de disco de Placido (Galilei G4, Ziemer Ophthalmic Systems AG, Suiça) foi usado para medir as mudanças na $A C D, A C A$ e PD, durante a acomodação. As medidas da ACD foram consideradas na zona central e em mais 4 posições, cada uma em orientação diferente (nasal, superior, temporal e inferior), a 4 milímetros de distância do centro. O ACA do olho inteiro, assim como nos quadrantes nasal, superior, temporal e inferior foram medidos. Todos estes indicadores foram obtidos por vários estímulos acomodativos, que variaram de +1 D a-4 D em intervalos de $1 \mathrm{D}$.

Resultados: $A$ ACD nãovariou significativamente com acomodação para qualquer determinada orientação, sendo a percentagem de variação relativa entre longe e visão de perto $-4,11 \%$ para a $A C D$ central (onde sinal negativo representa uma diminuição na $A C D$ ). Em relação ao ACA, este diminuiu significativamente em posições inferiores, temporais e superiores. O ACA total de olho e o ACA nasal não se alterou. Estas duas métricas oculares foram significativamente menores no par nasal-superior do que no temporal-inferior. Finalmente, PD diminuiu significativamente com a acomodação em cada vergência estudada, a mudança relativa após o estímulo de -4 D foi -8,13\%.

Conclusão: $A C A e P D$ variaram significativamente com a acomodação, enquanto $A C D$ não. Além disso, a câmara anterior se mostrou alterar assimetricamente, com a área nasal-superior se tornando significativamente mais rasa do que a temporal-inferior.

Descritores: Câmara anterior; Pupila; Acomodação ocular; Técnicas, medidas, equipamentos de medição

\section{INTRODUCTION}

The changes in anterior chamber depth (ACD), anterior chamber angle (ACA), and pupil diameter (PD) that occur during the eye's accommodation, have been extensively studied. Table 1 is a compilation of the results of all studies that evaluated at least one of these three eye metrics during accommodation. Studies assessing the changes in central $A C D^{(1-28)}$, mean $A C A^{(16)}$, and $\mathrm{PD}^{(3,7,26,28,29)}$ during accommodation concluded that these metrics decreased after increasing the stimulus vergence. Figure 1 is a side-by-side comparison of two Scheimpflug images that show central ACD for far vision and for -4 diopters (D) of accommodation.

The changes in the peripheral ACD and ACA at different meridians during accommodation have not been studied. Quantifying the possible position-related changes in ACD could enable the development of new intraocular lenses $(\mathrm{IOL})$ that preserve the anatomical structures (corneal endothelium, iris, or crystalline lens). Reports of studies assessing the changes in ACA along the horizontal and vertical meridians during accommodation are limited ${ }^{(16)}$. Further,
Submitted for publication: February 3, 2014

Accepted for publication: May 14,2014

Study conducted at University of Valencia.

Optometry Research Group (GIO), Department of Optics, University of Valencia, Spain.
Funding: This research was supported by the Starting Grant funded by the European Research Council (ERC-2012-StG-309416-SACCO) to Prof. Robert Montés-Micó, by a Atracció de talent research scholarship (Universidad de Valencia) awarded to Alberto Domínguez-Vicent, by a collaboration scholarship (Ministerio de Educación, Ciencia y Deporte) awarded to Daniel Molsálvez Romín.

Disclosure of potential conflicts of interest: None of the authors have any potential conflicts of interest to disclose.

Corresponding author: Alberto Domínguez Vicent. Department of Optics. University of Valencia. C/ Dr Moliner, 50 - 46100 - Burjassot - Spain - Email: alberto.vicent@uv.es 
Table 1. Results of reported studies that assessed the anterior chamber depth (ACD), anterior chamber angle (ACA), and pupil diameter (PD) with accommodation. The negative sign indicates a decrease in the ACD, ACA, or PD

\begin{tabular}{|c|c|c|c|c|c|c|c|}
\hline Reference & Device used & $\begin{array}{l}\text { Number of } \\
\text { eyes }\end{array}$ & $\begin{array}{l}\text { Mean age } \pm \text { SD } \\
\text { (age range) }\end{array}$ & $\begin{array}{l}\text { Refractive error } \pm \text { SD } \\
\text { (refractive error range) }\end{array}$ & Mean change in ACD (mm) & $\begin{array}{l}\text { ACA value } \\
\text { (degrees) }\end{array}$ & $\begin{array}{l}\text { Mean change } \\
\text { in PD value } \\
(\mathrm{mm})\end{array}$ \\
\hline Alderson et al. ${ }^{(1)}$ & Lenstar & 10 & $29(22-39)$ & $\begin{array}{c}-2.11 \pm 2.50 \\
(-6.00-+0.38)\end{array}$ & After -5 D: $-0.22 \pm 0.06$ & - & - \\
\hline Baikoff et al. (2) & OCT & 1 albino eye & 19 & 2 & After -10 D: -0.407 & - & - \\
\hline \multirow[t]{3}{*}{ Baikoff et al.(3) } & OCT & 104 & $39 \pm 15.20(7-82)$ & $(-5.00+5.00)$ & $\begin{array}{l}\text { After mamimum accommodation, } \\
\text { with } 20 \text { years: }-0.30\end{array}$ & - & $\begin{array}{l}\text { After }-10 \text { D in } \\
\text { dim light: }-1.5\end{array}$ \\
\hline & & & & & $\begin{array}{l}\text { After maximum accommodation, } \\
\text { with } 40 \text { years: }-0.10\end{array}$ & - & - \\
\hline & & & & & $\begin{array}{l}\text { After mamimum accommodation, } \\
\text { with } 65 \text { years: } 0.00\end{array}$ & - & - \\
\hline \multirow[t]{2}{*}{ Bolz et al. ${ }^{(4)}$} & $\mathrm{PCl}$ & 10 emmetropic & $23.00 \pm 2.40(19-31)$ & $\begin{array}{c}-0.03 \pm 0.08 \\
(-0.25-0)\end{array}$ & $\begin{array}{l}\text { After -1 D: }-0.01 \\
\text { After -2 D:-0.05 } \\
\text { After -3 D: }-0.12 \\
\text { After -4 D: }-0.19 \\
\text { After -5 D: }-0.27\end{array}$ & - & - \\
\hline & & 10 myopic & $24.70 \pm 3.90(19-31)$ & $\begin{array}{l}-4.70 \pm 1.50 \\
(-7.25--2.75)\end{array}$ & $\begin{array}{l}\text { After -1 D: }-0.33 \\
\text { After -2 D:-0.55 } \\
\text { After -3 D: }-0.14 \\
\text { After -4 D: }-0.22 \\
\text { After -5 D: }-0.25\end{array}$ & - & - \\
\hline Drexler et al. ${ }^{(5)}$ & $\mathrm{PCl}$ & 10 eyes & $30(25-39)$ & $(-5.25--0.25)$ & At near point:-0.186 \pm 0.09 & - & - \\
\hline Du et al. ${ }^{(6)}$ & UBM & 37 & $28.8 \pm 6.9(20-40)$ & $\begin{array}{c}-16.71 \pm 4.64 \\
(-23.86--8.63)\end{array}$ & $\begin{array}{c}\text { After pharmacological } \\
\text { accommodaion: } \\
\text { vertical: }-0.18 \pm 0.16 \\
\text { horizontal: }-0.15 \pm 0.09\end{array}$ & - & - \\
\hline Du et al. ${ }^{(7)}$ & UL-OCT & 41 & $33.5 \pm 6.9(21-41)$ & $-2.50 \pm 2.60$ & After -5 D: -1.43 & - & After -5 D: -1.117 \\
\hline Dubbelman et al. ${ }^{(8)}$ & $\begin{array}{c}\text { Scheimpflug } \\
\text { camera } \\
\text { (Nidek Eas-1000) }\end{array}$ & 65 & $32 \pm 9(16-51)$ & -1.4 & $\begin{array}{l}\text { Change per diopter: } \\
-0.048+0.0004^{*} \text { age }\end{array}$ & - & - \\
\hline Garner et al. ${ }^{(9)}$ & A-Scan & 11 & $21.2(18-28)$ & $\begin{array}{c}-1.88 \pm 1.64 \\
(-4.25-+0.50)\end{array}$ & $\begin{array}{l}\text { After -1.50 D: }-0.02 \\
\text { After -3.50 D: }-0.09 \\
\text { After -5.50 D: -0.20 } \\
\text { After -8.00 D: }-0.24\end{array}$ & - & - \\
\hline Kaluzny et al..(10) & $\begin{array}{l}\text { Ultrasound } \\
\text { biometry }\end{array}$ & 372 & $11.30 \pm 4.43(4-9)$ & $(-9.00-+9.00)$ & $\begin{array}{l}\text { After maximal accommodative } \\
\text { effort in: } \\
\text { emmetropic group: }-0.14 \pm 0.14 \\
\text { myopic group: }-0.07 \pm 0.13 \\
\text { hyperopic group: }-0.24 \pm 0.16\end{array}$ & - & - \\
\hline Kasthurirangan et al. ${ }^{(11)}$ & MRI & 15 & $22.8 \pm 3.1(19-29)$ & $\begin{array}{l} \pm 0.75 \text { D sphere less than } \\
0.50 \text { D cylinder }\end{array}$ & $\begin{array}{c}\text { At near viewing: }-0.31 \pm 0.30 \\
\text { mean diopters near viewing: } \\
{[6.9 \text { to } 4.8]}\end{array}$ & - & - \\
\hline Kirschkamp et al. ${ }^{(12)}$ & A-Scan & 9 & $(20-38)$ & - & After -4 D: -0.2 & - & - \\
\hline \multirow[t]{2}{*}{ Koivula et al. ${ }^{(13)}$} & $\mathrm{OCT}$ & 41 myopic & $24-49$ & $\begin{array}{c}-6.30 \\
(-14.50--3.50)\end{array}$ & After -4.50 D: -0.32 & - & - \\
\hline & & 11 hyperopic & & $\begin{array}{c}2.60 \\
(1.10-3.80)\end{array}$ & After -4.50 D: -0.28 & - & - \\
\hline Koretz et al. ${ }^{(14)}$ & $\begin{array}{l}\text { Scheimpflug } \\
\text { Slit lamp }\end{array}$ & 41 & $(18-40)$ & $(-2-+2)$ & After -1 D: $-0.037 \pm 0.026$ & - & - \\
\hline \multirow[t]{2}{*}{ Mallen et al. ${ }^{(15)}$} & IOLMaster & 30 emmetropic & $21.40 \pm 2.00$ & $-0.07 \pm 0.23$ & After -6.00 D: $-0.19 \pm 0.05$ & - & - \\
\hline & & 30 myopic & $21.5 \pm 2.10$ & $-3.59 \pm 0.75$ & After -6.00 D: $-0.18 \pm 0.03$ & & \\
\hline \multirow[t]{2}{*}{ Marchini et al. ${ }^{(16)}$} & UBM & $\begin{array}{l}26 \text { eyes with } \\
\text { monofocal IOL } \\
\text { implantation }\end{array}$ & $76 \pm 6(66-87)$ & - & After -3 D: $-0.03 \pm 0.30$ & $\begin{array}{c}\text { After }-3 \mathrm{D} \\
\text { horizontal: } \\
-1.22 \pm 5.81 \\
\text { vertical: } \\
-0.75 \pm 4.87\end{array}$ & - \\
\hline & $\begin{array}{l}\text { UBM } \\
\text { Hi-Scan }\end{array}$ & & & & After -3 D: $-0.04 \pm 0.09$ & $\begin{array}{l}\text { After }-3 \mathrm{D} \\
\text { horizontal: } \\
-1.08 \pm 3.53 \\
\text { vertical: } \\
-4.15 \pm 2.98\end{array}$ & - \\
\hline
\end{tabular}

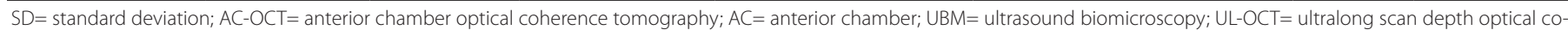

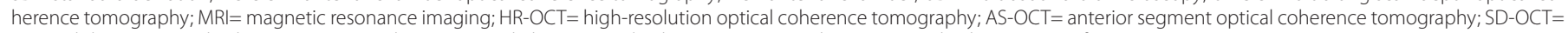
Spectral domain optical coherence tomography; SL-OCT= Slit lamp optical coherence tomography; $\mathrm{PCl}=$ Partial coherence interferometry. 
Table 1. Results of reported studies that assessed the anterior chamber depth (ACD), anterior chamber angle (ACA), and pupil diameter (PD) with accommodation. The negative sign indicates a decrease in the ACD, ACA, or PD (continued)

\begin{tabular}{|c|c|c|c|c|c|c|c|}
\hline Reference & Device used & $\begin{array}{l}\text { Number of } \\
\text { eyes }\end{array}$ & $\begin{array}{l}\text { Mean age } \pm \text { SD } \\
\text { (age range) }\end{array}$ & $\begin{array}{l}\text { Refractive error } \pm S D \\
\text { (refractive error range) }\end{array}$ & Mean change in ACD (mm) & $\begin{array}{l}\text { ACA value } \\
\text { (degrees) }\end{array}$ & $\begin{array}{l}\text { Mean change } \\
\text { in PD value } \\
(\mathrm{mm})\end{array}$ \\
\hline \multirow[t]{2}{*}{ Malyugin et al..(17) } & OCT & 31 emmetropic & $25.9 \pm 2.3(20-33)$ & $-0.39 \pm 0.33(-1.00-0.13)$ & $\begin{array}{l}\text { After -1 D: }-0.03 \pm 0.03 \\
\text { After -3 D: }-0.12 \pm 0.06 \\
\text { After -6 D: }-0.19 \pm 0.08 \\
\text { After -10 D: }-0.21 \pm 0.08\end{array}$ & - & - \\
\hline & & 36 myopic & $26.6 \pm 4.5(19-35)$ & $12.52 \pm 4.07(-20.00--6.25)$ & $\begin{array}{l}\text { After -1 D: }-0.05 \pm 0.03 \\
\text { After -3 D: }-0.09 \pm 0.05 \\
\text { After -6 D: }-0.12 \pm 0.07 \\
\text { After -10 D: }-0.13 \pm 0.06\end{array}$ & - & - \\
\hline \multirow[t]{2}{*}{ Ni et al..(18) } & Pentacam HR & 23 & $24.40 \pm 2.60(18-29)$ & 0.00 & After -5 D: -0.11 & - & - \\
\hline & & 15 & $55.70 \pm 5.10(43-58)$ & 0.00 & After -1 D: -0.01 & - & \\
\hline Ostrin et al. ${ }^{(19)}$ & A-Scan & 22 & $25.80 \pm 2.30(21-30)$ & $\begin{array}{l}\text { Right eye }-2.53 \pm 1.98 \\
\quad(-6.00-+0.75) \\
\text { Left eye: }-2.52 \pm 2.19 \\
(-5.75-+2.75)\end{array}$ & After -1 D: $-0.051 \pm 0.01$ & - & - \\
\hline Read et al. ${ }^{(22)}$ & Pentacam HR & 11 & $24(20-30)$ & $\begin{array}{l}\text { Sphere: }(0.25-+0.50) \\
\text { Cylinder: }(-0.25-0.00)\end{array}$ & After -5 D: $-0.14 \pm 0.05$ & - & - \\
\hline \multirow[t]{2}{*}{ Read et al..(23) } & Lenstar & 19 emmetropic & $25 \pm 4(18-33)$ & $-0.05 \pm 0.27$ & $\begin{array}{l}\text { After }-3 \text { D: }-0.10 \pm 0.09 \\
\text { After }-6 \text { D: }-0.30 \pm 0.14\end{array}$ & - & - \\
\hline & & 21 myopic & & $-1.82 \pm 0.84$ & $\begin{array}{l}\text { After }-3 \text { D: }-0.14 \pm 0.11 \\
\text { After }-6 \text { D: }-0.29 \pm 0.14\end{array}$ & - & - \\
\hline Ruggeri et al. ${ }^{(24)}$ & OCT & 2 & 35 & & After -4 D: -0.07 & - & - \\
\hline \multirow[t]{2}{*}{ Tsorbatzoglou et al. ${ }^{(25)}$} & $\mathrm{PCl}$ & 32 & $(16-30)$ & $-0.05 \pm 0.13$ & After -4.50 D: $-0.08 \pm 0.06$ & - & - \\
\hline & & 37 & $(31-44)$ & $-0.03 \pm 0.32$ & After -3.00 D: $-0.06 \pm 0.09$ & - & \\
\hline & & 42 hyperopic & $(41-60)$ & $+0.25-+1.75$ & $\begin{array}{c}\text { After maximum } \\
\text { amplitude of accommodation: } \\
-0.06 \pm 0.04\end{array}$ & - & $\begin{array}{l}\text { After maximum } \\
\text { amplitude of } \\
\text { accommodation: } \\
-0.26 \pm 0.25\end{array}$ \\
\hline Yuan et al.(27) & OCT & 20 & $33.1 \pm 5.8$ & $-2.76 \pm 2.61(-6.88-0.00)$ & $\begin{array}{c}\text { After maximal } \\
\text { accommodation -0.05 }\end{array}$ & - & $\begin{array}{l}\text { After maximal } \\
\text { accommodation } \\
\sim 0.65\end{array}$ \\
\hline Zhou et al. ${ }^{(28)}$ & OCT & 1 & 37 & -3.5 & $\begin{array}{l}\text { After -2 D: }-0.02 \\
\text { After -5.50 D: -0.13 }\end{array}$ & - & - \\
\hline \multirow[t]{2}{*}{ Charman et al. (29) } & Hartmann-Shack & 20 emmetropic & $25.30 \pm 5.70$ & $-0.07 \pm 0.26(-0.50-+0-50)$ & - & - & $\begin{array}{l}\text { After }-1 \mathrm{D}: \\
-0.21 \pm 0.15\end{array}$ \\
\hline & & 20 myopic & $23.10 \pm 4.50$ & $-3.06 \pm 2.35(-8.45--0.60)$ & - & - & $\begin{array}{l}\text { After }-1 \mathrm{D}: \\
-0.31 \pm 0.29\end{array}$ \\
\hline
\end{tabular}

$\mathrm{SD}=$ standard deviation; $\mathrm{AC}-\mathrm{OCT}=$ anterior chamber optical coherence tomography; $\mathrm{AC}=$ anterior chamber; $\mathrm{UBM}=$ ultrasound biomicroscopy; $\mathrm{UL}-\mathrm{OCT}=$ ultralong scan depth optical $\mathrm{CO}-$ herence tomography; MRI= magnetic resonance imaging; $\mathrm{HR}$-OCT = high-resolution optical coherence tomography; AS-OCT= anterior segment optical coherence tomography; SD-OCT= Spectral domain optical coherence tomography; SL-OCT = Slit lamp optical coherence tomography; $\mathrm{PCl}=$ Partial coherence interferometry.

no previous studies assessed the possible changes in ACA during accommodation in young population. Such studies will enable the development of new anterior chamber IOLs that better fits the anterior chamber eye. Several studies have evaluated the changes in pupil diameter during accommodation ${ }^{(3,7,26,28,29)}$. However, four of these studies $(3,7,26,28)$ included myopic or hyperopic subjects and mea- 


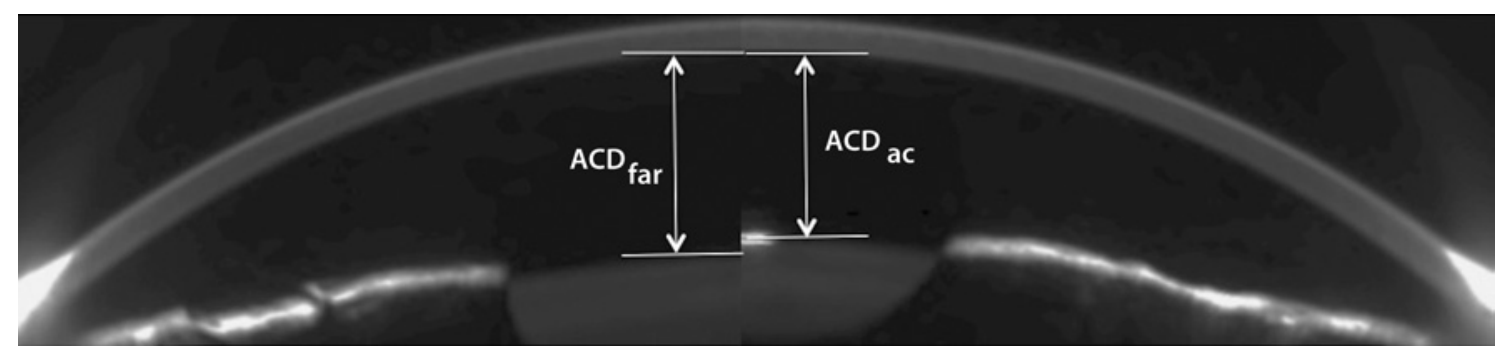

Figure 1. Scheimpflug images obtained with the measuring device, which combines a rotating Dual Scheimpflug and a Placido disc system (Galilei G4, Ziemer Ophthalmic Systems AG, Switzerland). The images represent changes in the anterior chamber depth (ACD) for far vision and after -4 Diopters of accommodation in the same subject. $A C D_{a c}$ represents the central $A C D$ during accommodation. $A C D_{\text {far }}$ represents the central $A C D$ for far vision.

sured the changes in pupil diameter with stimuli vergences beyond 5 D. Further, a Scheimpflug system has not been used to study the changes in pupil that occur during accommodation.

The aim of the present study was to evaluate the changes in ACD, $A C A$, and PD during accommodation. For this purpose the rotating Dual Scheimpflug and a Placido disc system (Galilei G4, Ziemer Ophthalmic Systems AG, Switzerland) was chosen as a measuring devices. To our knowledge, this is the first comprehensive study that evaluated all of these ocular metrics during accommodation.

\section{METHODS}

\section{STUDY COHORT}

Eighty right eyes from eighty subjects (39 men and 41 women), whose ages ranged from 20 to 40 years (mean \pm standard deviation $=$ $30.36 \pm 7.32$ years), with a mean spherical equivalent of $0.80 \pm 0.73$ diopters (D) were included in the study. All patients were informed of the details of this study and a written informed consent was obtained in accordance with the Helsinki Declaration. An Institutional Review Board approval was not required for this study. Subjects with best-corrected visual acuity below than 20/40, ocular or systemic disease, history of ocular surgery, intraocular pressure above $21 \mathrm{mmHg}$, or retinal or optic disk pathology were excluded from the study.

\section{Measuring device and StUdy metrics}

\section{Measuring device}

The rotating Dual Scheimpflug and a Placido disc system (Galilei G4, Ziemer Ophthalmic Systems AG, Switzerland) (Figure 2) is one of the latest versions of the Galilei topographer. This device integrated both the Placido and rotated Dual Scheimpflug images to generate a three-dimensional model of the anterior eye segment. This device also recorded images of the cornea, iris, pupil, limbus, anterior chamber, and the lens. Additionally, the Galilei G4 has a red-LED near/far adjustable fixation target, which can be moved in 0.25-D steps from $-20 \mathrm{D}$ to $+20 \mathrm{D}$.

\section{Eye metrics}

The Galilei G4 was used to record the central and peripheral ACD, mean ACA of the whole eye, local ACA, and the PD. These eye metrics were measured for far, intermediate, and near vision. The central ACD was measured automatically as the distance between the corneal endothelium and the anterior surface of the crystalline lens. The peripheral ACD was measured $4 \mathrm{~mm}$ away from the corneal centre, and was defined as the distance between the corneal endothelium and the iris. This eye metric, which had a resolution of $0.01 \mathrm{~mm}$, was measured manually from the Scheimpflug images at 0 degrees (to measure nasal and temporal ACD) and at 90 degrees (to measure superior and inferior ACD). The ACA was measured automatically as the intersection between the posterior corneal surface and the iris, with a resolution of 0.1 degrees. The ACA of the whole eye was calculated as the average value generated from the 3-D model. This eye metric was also measured individually at the nasal, temporal, superior, and inferior positions. Finally, the PD was computed as the diameter of the best-fit circle for the central image, with a resolution of $0.01 \mathrm{~mm}$.

\section{EXPERIMENTAL PROCEDURE}

Before each measurement, the central Placido rings were focused and the instrument was aligned. Following this, a volunteer was requested to blink and look at the fixation target for 2 seconds to get an appropriate accommodation response ${ }^{(30)}$. Then, to avoid distortion, the subject was requested to not to blink during the measurement. To ensure that all measurements were made under the same lighting conditions, the experiments were performed in dark.

The ACD, ACA, and PD were measured for a viewing distance that

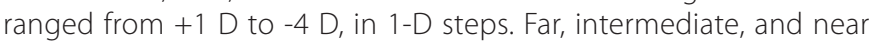
vision ranged from $+1 \mathrm{D}$ to $0 \mathrm{D},-1 \mathrm{D}$ to $-2 \mathrm{D}$, and $-3 \mathrm{D}$ to $-4 \mathrm{D}$, respectively. These parameters were used so as to study the changes in the anterior eye segment during the most common accommodative effort. Three measurements were made for each accommodation stimuli and the average value was retained. A single specialist, who had prior experience operating this device and who also was not aware of the study's goal, carried out all experiments. For each subject, all measurements were made within a single session.

\section{Statistical analysis}

SigmaPlot for Windows version 11 (Systat Software, Inc.) was used for the statistical analysis of the data. Since the main goal was to compare the values obtained under different conditions such as accommodative stimulus and anatomical location, the study had a factorial design. Therefore, once the normality assumption was confirmed using the Shapiro-Wilk test, the repeated-Measures ANOVA was chosen as the most suitable test. The Post-Hoc multiple-comparison test by means of the Holm Sidak method was then performed in those cases where the ANOVA revealed differences. The threshold of statistical significance was set at $P=0.05$.

For ACD, a Two-Way Analysis of Variance was performed, whose two factors were "accommodative stimulus" and "location". For the analysis of the pupil size and mean ACA, the One-Way Analysis of Variance was chosen, with "accommodative stimulus" as its main factor. Finally, for location-dependent ACA, the Two-Way Analysis of Variance was used, with "location" and "accommodative stimulus" as the two factors.

\section{RESULTS}

\section{Anterior ChAMber DePTH}

Table 2 summarizes the ACD values for each accommodation stimuli and position. The percentage of relative change between far and near vision was $-4.11 \%, 7.57 \%,-2.11 \%, 7.56 \%$, and $-0.51 \%$ for central, superior, inferior, nasal, and temporal $A C D$, respectively, where 


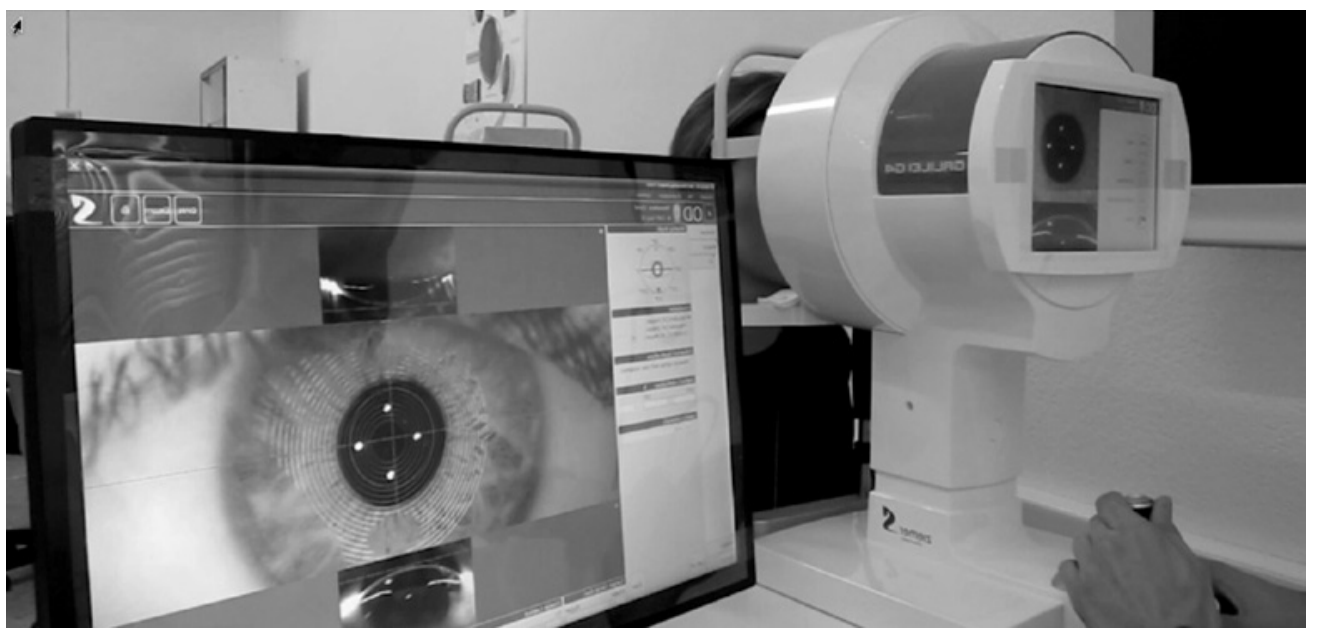

Figure 2. Photograph of the measuring device used in this study.

Table 2. Mean anterior chamber depth (ACD), anterior chamber angle (ACA), and pupil diameter (PD) for far (0 D) and near vision (-4 D) ACD and pupil diameter are expressed in $\mathrm{mm}$ and $\mathrm{ACA}$ in degrees

\begin{tabular}{|c|c|c|c|c|c|c|c|c|c|c|c|}
\hline & \multicolumn{5}{|c|}{ Anterior chamber depth } & \multicolumn{5}{|c|}{ Anterior chamber angle } & \multirow{2}{*}{$\begin{array}{c}\text { Pupil diameter } \\
\text { Mean }\end{array}$} \\
\hline & Central & Superior & Inferior & Nasal & Temporal & Mean & Superior & Inferior & Nasal & Temporal & \\
\hline OD & $3.07 \pm 0.08$ & $1.58 \pm 0.11$ & $1.79 \pm 0.12$ & $1.43 \pm 0.09$ & $1.97 \pm 0.09$ & $34.72 \pm 2.48$ & $33.47 \pm 0.95$ & $36.18 \pm 0.84$ & $34.32 \pm 0.96$ & $36.49 \pm 0.82$ & $3.08 \pm 0.16$ \\
\hline$-1 D$ & $3.05 \pm 0.08$ & $1.64 \pm 0.11$ & $1.76 \pm 0.11$ & $1.49 \pm 0.11$ & $2.08 \pm 0.10$ & $34.73 \pm 1.77$ & $33.92 \pm 0.67$ & $36.75 \pm 1.04$ & $33.94 \pm 0.75$ & $36.60 \pm 0.68$ & $2.91 \pm 0.15$ \\
\hline$-2 D$ & $3.02 \pm 0.08$ & $1.57 \pm 0.09$ & $1.82 \pm 0.13$ & $1.53 \pm 0.11$ & $2.06 \pm 0.11$ & $34.46 \pm 1.91$ & $33.79 \pm 0.64$ & $36.52 \pm 0.79$ & $33.62 \pm 0.68$ & $35.82 \pm 0.59$ & $2.90 \pm 0.11$ \\
\hline$-3 D$ & $2.94 \pm 0.07$ & $1.57 \pm 0.10$ & $1.84 \pm 0.12$ & $1.52 \pm 0.09$ & $2.06 \pm 0.11$ & $33.77 \pm 1.98$ & $33.00 \pm 0.83$ & $34.72 \pm 0.66$ & $33.86 \pm 0.53$ & $34.29 \pm 1.24$ & $2.84 \pm 0.11$ \\
\hline$-4 D$ & $2.95 \pm 0.07$ & $1.68 \pm 0.11$ & $1.73 \pm 0.11$ & $1.53 \pm 0.11$ & $1.96 \pm 0.11$ & $33.36 \pm 1.58$ & $31.72 \pm 0.56$ & $34.24 \pm 0.36$ & $32.57 \pm 1.10$ & $35.00 \pm 0.49$ & $2.75 \pm 0.11$ \\
\hline
\end{tabular}

the negative values indicate a decrease in the ACD and the positive values suggest an increase in ACD. No statistical significant differences were observed in this eye metric among far vision and each accommodation stimuli.

The highest ACD was obtained at the central position. The quadrant nasal-superior was significantly shallower than the temporalinferior quadrant. Further, comparable values were obtained between each pair (nasal-superior, and temporal-inferior). This behaviour was also observed at far and near vision.

\section{Anterior Chamber ANGLe}

Table 2 summarizes the ACA values for each accommodation-stimuli and position. The percentage of relative change in ACA between far and near visions was $-4.55 \%,-3.72 \%,-4.71 \%,-5.07 \%$ and $-3.73 \%$ for nasal, temporal, superior, inferior, and mean ACA, respectively. Whereas the mean ACA at the nasal position and of the whole eye did not vary significantly with accommodation, significant variation was observed in other positions. A significant reduction in ACA at temporal position was obtained among $-3.00 \mathrm{D}$ and $-1.00 \mathrm{D}$ and $0 \mathrm{D}$; among $-4.00 \mathrm{D}$ and $-1.00 \mathrm{D}$ and $-2.00 \mathrm{D}$ at superior position, and among $-4.00 \mathrm{D}$ and $0.00 \mathrm{D},-1.00 \mathrm{D}$ and $-2.00 \mathrm{D}$ at the inferior position.

The nasal-superior quadrant had significantly lower ACA than the temporal-inferior quadrant. Further, comparable ACA was obtained between each pair (nasal-superior and temporal-Inferior).

\section{Pupil diameter}

Table 2 also highlights the absolute PD with accommodation. The PD was reduced $-8.31 \%$ between far and near visions, and the difference became significant between $-4.00 \mathrm{D}$ and $-3.00 \mathrm{D}$ and between $-1.00 \mathrm{D}$ and $-4.00 \mathrm{D}$.

\section{DISCUSSION}

The objective of the present study was to assess the changes in $A C D, A C A$ and, PD during accommodation.

\section{Anterior chamber Depth}

The central ACD did not change significantly ( $P>0.05)$ with accommodation, the mean change between far and near vision being 0.13 $\pm 0.13 \mathrm{~mm}$. A number of studies (Table 1) have assessed the changes in central ACD during accommodation. Our results are in agreement with those found previously in emmetropic volunteers $(4,15,17,18,22,23,25,26)$. Bolz et al. ${ }^{(4)}$, who used partial coherence interferometry, found a relative ACD decrease of $4.92 \%$ after -4.00 D of vergence. Mallen et al. ${ }^{(15)}$ studied the changes in ACD during accommodation using the IOLMaster. The ACD obtained after -6 D accommodation was 5\% shallower than that measured for far vision. Malyugin et al. ${ }^{(17)}$, Read et al. ${ }^{(23)}$, and Tsorbatzoglou et al. ${ }^{(25)}$ studied changes in ACD after $-3.00 \mathrm{D}$ of accommodation and found that the relative changes were $3.80 \%$, $3.20 \%$ and $2.23 \%$, respectively. Finally, Ni et al ${ }^{(18)}$ and Read et al ${ }^{(22)}$ also studied the changes in ACD with accommodation in young eyes with the help of Pentacam HR. After -5 D accommodation, the mean ACD decreased approximately by $0.11 \mathrm{~mm}$ and $0.14 \mathrm{~mm}$, respectively.

However, Yan et al. ${ }^{(26)}$ found greater changes than that observed in previous studies. The central ACD decreased by $0.25 \pm 0.09 \mathrm{~mm}$. This magnitude of change is approximately $0.12 \mathrm{~mm}$ greater than that found in our study. The difference between our results and that of Yan et al. ${ }^{(26)}$ could be due to the stimulus vergence range under analysis. Whereas the highest vergence in our study was $-4 \mathrm{D}$, a vergence was not reported by Yan et al. since these authors used the subject's maximum amplitude of accommodation. 
Our results also showed that the ACD is asymmetrical along the eye (Table 2), where the quadrant superior-nasal was significantly shallower than the quadrant inferior-temporal. These results are in agreement with those reported by Koç et al. ${ }^{(27)}$, who studied the anterior chamber width with the help of a Scheimpflug camera. These authors found that the superior-nasal quadrant was significantly narrower than the inferior-temporal quadrant. However, our results contradict the results of Marigo et al. ${ }^{(31)}$, who used ultrasound biomicroscopy (UBM) for their studies. These authors found that the angle opening distance at 250 and $500 \mu \mathrm{m}$ from the scleral spur was shallower at the horizontal direction than that in the vertical direction. These differences could be related to the different methodologies used in the studies. It can be concluded that ACD is asymmetrical along the anterior chamber eye. Further studies are needed to clarify these contradictions and to propose safer IOL designs, where thickness should be asymmetrical in order to avoid possible damage in the corneal endothelium.

\section{Anterior Chamber ANGLE}

The ACA of the whole eye changed during accommodation. The relative decrease in ACA was 3.73\%. However, the local ACA varied significantly with accommodation. The highest and lowest relative decreases in the ACA after -4 D of accommodation was $5.07 \%$ (at inferior position) and 3.72\% (at temporal position), respectively. The superior-nasal ACA was significantly narrower than the temporalinferior ACA. Therefore, it can be concluded that ACA varies in an asymmetrical manner along the anterior chamber eye. These results are in agreement with those of Koç et al. ${ }^{(27)}$, who studied the ACA width at different quadrants. These authors found that the superiornasal quadrant was significantly narrower than the temporal-inferior quadrant. Further, these results are in agreement with ACD ones because the nasal-superior ACD was significantly shallower than the temporal-inferior ACD. However, our results contradict those reported by Marigo et al. ${ }^{(31)}$, who found shallower angle opening distance at the horizontal direction than in the vertical direction. As discussed earlier, these discrepancies might be related to the different devices used in these studies. To propose a suitable method for placing an angular support IOL, future studies should clarify the ACA symmetry.

To the best of our knowledge, this is the first report that describes the changes in ACA during accommodation ${ }^{(16)}$ in subjects who underwent IOL implantation and whose mean age was $76 \pm 6$ years. After $3 \mathrm{D}$ of accommodation, the ACA decreased by approximately 1.22 degrees at the horizontal meridian and by 0.75 degrees in the vertical direction. Considering the mean changes in ACA along the horizontal and vertical directions, the mean ACA were approximately 1.35 and 0.95 degrees, respectively. These values are higher than that reported by Marchini et al. These disagreements could be related to the differences in sample population. We included phakic eyes, whereas Marchini et al. used aphakic eyes with an implanted IOL. Additionally, the mean age of our sample population was $25.30 \pm 2.98$ years, whereas the mean age of subjects in the study reported by Marchini et al. was $76.60 \pm 6.0$ years.

\section{Pupil diameter}

The mean relative change in PD between far and near vision was 8.31\%. Yan et al. (26) measured PD up to the maximum amplitude of accommodation in emmetropic subjects using an SL-OCT system and found that the relative decrease in PD was 20.83\%. Yuan et al. ${ }^{(28)}$, who measured the changes in PD during accommodation using a spectral-domain OCT system in myopic subjects, found a relative decrease of $15.80 \%$. The differences between the results of earlier studies and that of the present study are likely due to the different methods of measurements adopted. The earlier studies used the full accommodation interval without specifying the maximum vergence value. Another possible reason for the discrepancies may be the differences in the luminance conditions used in each device.
Using ultralong scan depth optical coherence tomography, Du et al. ${ }^{(7)}$ measured dimensional changes in the anterior segment of human eyes during accommodation. The relative change in the pupil diameter with a maximum accommodation effort of -5 D was $21.74 \%$. The differences between the PD values obtained in the present study and that of Du et al. likely occurred due to the different samples studied. Whereas Du et al. included myopic subjects, the subjects in our study were emmetropic.

Baikoff et al. ${ }^{(4)}$ used anterior-chamber OCT (AC-OCT) to measure variations in $\mathrm{PD}$ at $-10 \mathrm{D}$ of accommodation in dim light. These authors reported a mean change in PD of $1.5 \mathrm{~mm}$. The differences between our results and those of Baikoff et al. could be related to the different experimental conditions used. Baikoff et al. used-10 D as the maximum accommodation, whereas the maximum accommodation stimulus in our study was -4 D. Chartman et al. ${ }^{(29)}$ studied changes in pupil size during accommodation using a Hartman-Shack wavefront sensor. The mean rate of change in PD during accommodation was $-0.21 \pm 0.15 \mathrm{~mm} \cdot \mathrm{D}^{-1}$. Our results are in agreement with those reported by Chartman et al., as the mean change in PD after $-1 \mathrm{D}$ accommodation in our study was $0.16 \pm 0.31 \mathrm{~mm}$.

One limitation of our study is that only emmetropic subjects were considered. A second limitation is that all measurements were performed with only one device. Future efforts should focus on studying the changes in the anterior segment during accommodation in myopic and hyperopic subjects using other devices.

In summary, the ACA and PD varied significantly with accommodation, whereas variations in ACD were not observed. The anterior chamber eye was found to be asymmetrical, with the nasal-superior area being significantly shallower than the temporal-inferior area.

\section{REFERENCES}

1. Alderson A, Davies LN, Mallen EA, Sheppard AL. A method for profiling biometric changes during disaccommodation. Optom Vis Sci. 2012;89(5):E738-E748.

2. Baikoff G, Lutun E, Wei J, Ferraz C. Anterior chamber optical coherence tomography study of human natural accommodation in a 19-year-old albino. J Cataract Refract Surg. 2004;30(3):696-701.

3. Baikoff G, Lutum E, Ferraz C, Wei J. Static and dynamic analysis of the anterior segment with optical coherence tomography. J Cataract Refract Surg. 2004;30(9):1843-50.

4. Bolz M, Prinz A, Drexler W, Findl O. Linear relationship of refractive and biometric lenticular changes during accommodation in emmetropic and myopic eyes. $\mathrm{Br} J$ Ophthamol. 2007;91(3):360-5

5. Drexler W, Baumgartner AA, Findl O, Hitzenberger CK, Fercher AF. Biometric investigation of changes in the anterior eye segment during accommodation. Vision Res. 1997;37(19):2789-800.

6. Du C, Wang J, Wang X, Dong Y, Gu Y, Shen Y. Ultrasound biomicroscopy of anterior segment accommodative changes with posterior chamber phakic intraocular lens in high myopia. Ophthalmology. 2012;119(1):99-105.

7. Du C, Shen M, Li M, Zhu D, Wang MR, Wang J. Anterior segment biometry during accommodation imaged with ultralong scan depth optical coherence tomography. Ophthalmology. 2012;19(12):2479-85.

8. Dubbelman M, van der Heijde GL, Weeber HA. Change in shape of the aging human crystalline lens with accommodation. Vision Res. 2005;45(1):117-32.

9. Garner LF, Yap MK. Changes in ocular dimensions and refraction with accommodation. Ophthalmic Physiol Opt. 1997;17(1):12-7.

10. Kaluzny BJ. Anterior movement of the crystalline lens in the process of accommodation in children. Eur J Ophthalmol. 2007;17(4):515-20.

11. Kasthurirangan S, Markwell EL, Atchison DA, Pope JM. MRI study of the changes in crystalline lens shape with accommodation and aging in human. J Vis. 2011:11(3):19,1-16.

12. Kirschkamp T, Dunne M, Barry JC. Phakometric measurement of ocular surface radi of curvature, axial separations and alignment in relaxed and accommodated human eyes. Ophthalmic Physiol Opt. 2004;24(2):65-73.

13. Koivula A, Kulgelberg M. Optical coherence tomography of the anterior segment in eyes with phakic refractive lens. Ophthalmology. 2007;114(11):2031-7.

14. Koretz JF, Cook CA, Kaufman PL. Accommodation and presbyopia in the human eye Changes in the anterior segment and crystalline lens with focus. Invest Ophthalmol Vis Sci. 1997;38(3):569-78.

15. Mallen EA, Kashyap P, Hampson K. Transien axial length change during the accommodation response in young adults. Invest Ophthalmol Vis Sci. 2006:47(3):1251-4.

16. Marchini G, Pedrotti E, Modesti M, Visentin S, Tosi R. Anterior segment changes during accommodation in eyes with a monofocal intraocular lens: High-frequency ultrasound study. J Cataract Refract Surg. 2008;34(6):949-56. 
17. Malyugin BE, Shpak AA, Pokrovskiy DF. Accommodative changes in anterior chamber depth in patients with high myopia. J Cataract Refract Surg. 2012;38(8):1403-7.

18. Ni Y, Liu XL, Wu MX, Lin Y, Sun YY, He C, et al. Objective evaluation of the changes in the crystalline lens during accommodation in young and presbyopic populations using Pentacam HR system. Int J Ophthalmol. 2011;4(6):611-5.

19. Ostrin L, Kasthurirangan S, Hall DW, Glasser A. Simultaneous measurement of refraction and A-scan biometry during accommodation in humans. Optom Vis Sci. 2006:83(9):657-65.

20. Petternel V, Köppl CM, Ruhswurm ID, Findl O, Skorpik C, Drexler W. Effect of accommodation and pupil size on the movement of a posterior chamber lens in the phakic eye. Ophthalmology. 2004;111(2):325-31.

21. Poinooswamy D, Nagasubramanian S, Brown NA. Effect of pilocarpine on visual acuity and on the dimensions of the cornea and anterior chamber. Brit J Ophthal. 1976; 60(10):676-9.

22. Read S, Buehren T, Collins M. Influence of accommodation on the anterior and posterior cornea. J Cataract Refract Surg. 2007:33(11):1877-85.

23. Read S, Collins M, Woodman E, Cheong S. Axial Length Changes During Accommodation in Myopes and Emmetropes. Optom Vis Sci. 2010;87(9):656-62.

24. Ruggeri M, Uhlhorn SR, de Freitas C, Ho A, Manns F, Parel JM. Imaging and full-length biometry of the eye during accommodation using spectral domain OCT with an optical switch. Biomed Opt Express. 2012:3(7):1506-20.
25. Tsorbatzoglou A, Németh G, Széll N, Biró Z Berta A. Anterior segment changes with age and during accommodation measured with partial coherence interferometry. J Cataract Refract Surg. 2007;33(9):1597-601.

26. Yan PS, Lin HT, Wang QL, Zhang ZP. Anterior segment variations with age and accommodation demonstrated by slit-lamp adapted optical coherence tomography. Ophthalmology. 2010;117(12):2301-7.

27. Koç M, Özülken K, Ayar O, Karakurt A. Measurement of the anterior chamber angle according to quadrants and age groups using Pentacam Scheimpflug camera. J Glaucoma. 2013;22(3):226-9.

28. Yuan Y, Chen F, Shen M, Lu F, Wang J. Repeated measurements of the anterior segment during accommodation using long scan depth optical coherence tomography. Eye Contact Lens. 2012;38(2):102-8.

29. Charman WN, Radhakrishnan. Accommodation, pupil diameter and myopia. Ophthalmic Physiol Opt. 2009;29(1):72-9

30. López-Gil, Fernández-Sánchez V, Legras R, Montés-Micó R, Lara F, Nguyen-Khoa. Accommodation-related changes in monochromatic aberrations of human eyes as a function of age. Invest Ophthalmol Vis Sci. 2008;49(4):1736-43.

31. Marigo F, Filho E, Marigo P, Oliveira A, Cronemberger S. Symmetry of the anterior segment morphometric measurement in paired eyes using ultrasound biomicoroscopy (UBM). Arq Bras Ophthalmol. 2007;70(2):330-6.

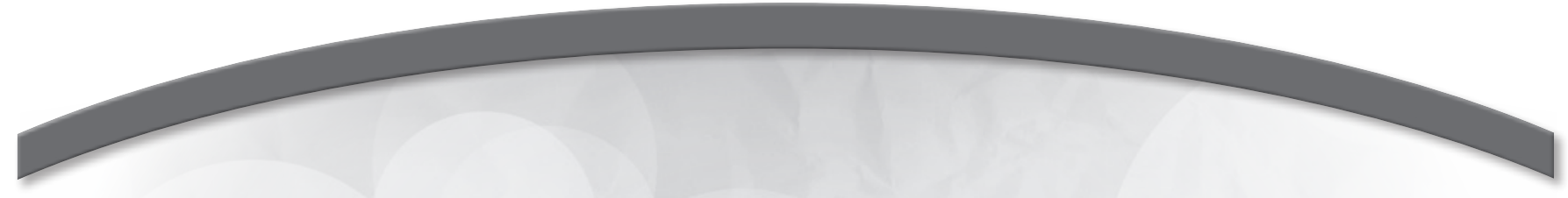

XXV Congresso Cearense de Oftalmologia

13 a 15 de novembro de 2014

Hotel Oásis Atlântico

Fortaleza-CE

Informações:

Tel.: (85) 3264-9404

E-mail: sco@sco.med.br 